\title{
Prognostic impact and concordance of TERT promoter mutation and protein expression in matched primary and metastatic cutaneous melanoma
}

\author{
Emilia Hugdahl ${ }^{\star}, 1$, May Britt Kalvenes ${ }^{1}$, Monica Mannelqvist ${ }^{1}$, Rita G Ladstein ${ }^{1,2}$ and Lars A Akslen ${ }^{*, 1,3}$ \\ ${ }^{1}$ Centre for Cancer Biomarkers CCBIO, Department of Clinical Medicine, University of Bergen, Bergen 5021, Norway; ${ }^{2}$ Department \\ of Dermatology, Haukeland University Hospital, Bergen 5021, Norway and ${ }^{3}$ Department of Pathology, Haukeland University \\ Hospital, Bergen 5021, Norway
}

Background: TERT promoter mutations are frequent in melanoma. Here we analysed the concordance and prognostic impact of TERT mutation and telomerase reverse transcriptase (TERT) protein expression in a large melanoma series.

Methods: In 194 primary nodular melanomas with 72 matched loco-regional metastases, TERT promoter mutation status was assessed by Sanger sequencing and TERT protein expression by immunohistochemistry.

Results: TERT mutations were found in $68 \%$ of primary melanomas and $64 \%$ of metastases, and the mutation status was discordant between primary tumour and metastasis in $24 \%$ of the cases. 6 of the 10 cases with discordant and wild-type metastases were also TERT wild type when re-tested in other intra-tumour regions, whereas 4 cases were mutation positive. TERT-mutated tumours tended to be thicker, have a higher mitotic count and higher patient age than TERT wild-type cases, but there was no significant association with reduced survival. TERT protein expression did not correlate with mutation status, but showed a similar discordancy between the primary and first metastatic lesion, and was significantly associated with reduced survival.

Conclusions: TERT promoter mutations showed inter- and intra-tumoural discordancy, whereas only expression of TERT protein was associated with reduced patient survival.

Whereas replicative immortality is one of the hallmarks of cancer (Hanahan and Weinberg, 2011), the presence of telomeres create a replication limit in somatic cells. Cancer cells can bypass this limit by reactivating telomerase which is mostly dependent on the amount of telomerase reverse transcriptase (TERT). A high frequency of TERT promoter mutations was first discovered in cutaneous melanoma (Horn et al, 2013; Huang et al, 2013) and this was later reported for several different cancers (Killela et al, 2013; Vinagre et al, 2013). TERT mutations enhance the expression of the TERT gene by creating de novo binding motifs for different transcription factors (Huang et al, 2013). Thus, multiple mechanisms for telomerase reactivation have been described in TERT mutant tumours, such as induction of NF- $\kappa \beta$ signalling and GABPA transcription factors (Bell et al, 2015; Li et al, 2015; Stern et al, 2015; Akincilar et al, 2016). There are three previous studies reporting a prognostic significance of TERT promoter mutations in primary melanomas (Griewank et al, 2014; Populo et al, 2014; Nagore et al, 2016a), whereas Ofner et al (2016) and Ekedahl et al (2016) found no such impact in their series of primary and metastatic melanomas. With the exception of a limited study including six cases of paired primary melanoma and metastatic tumours (Heidenreich et al, 2014), the question whether TERT

*Correspondence: Dr E Hugdahl; E-mail: Emilia.Hugdahl@k1.uib.no or Professor LA Akslen; E-mail: Lars.Akslen@k1.uib.no

Received 12 May 2017; revised 13 September 2017; accepted 2 October 2017; published online 9 November 2017

(C) 2018 Cancer Research UK. All rights reserved 0007 - 0920/18 
promoter mutation status change during melanoma tumour progression has not been investigated. Further, the protein expression of TERT in cutaneous melanoma is not well described. In a report by Populo et al (2014), TERT expression was not associated with TERT mutation or survival, whereas Zygouris et al (2007) found that TERT protein expression was associated with tumour thickness and ulceration.

In the present study, we investigated whether TERT promoter mutations are associated with an aggressive phenotype and reduced survival in a series of nodular melanomas and matched loco-regional metastases. Using a large cohort of matched metastases, we studied whether the mutational status is concordant between primary and metastatic tumours, and whether there are differences between various metastases from the same patients. We also examined TERT protein expression to see whether this correlates with mutation status, clinico-pathologic features and survival.

\section{MATERIAL AND METHODS}

Patients. This patient series include 255 consecutive cases of primary nodular cutaneous melanomas diagnosed at the Department of Pathology, Haukeland University Hospital (Bergen, Norway) during 1998-2008 (Ladstein et al, 2012a). There was no known history of familial occurrence. During this time period, the sentinel node procedure was not performed in Norway; this patient series therefore lacks complete staging. Cases with sufficient tissue for Sanger sequencing $(n=194)$ were thicker, more often ulcerated and had a higher mitotic count when compared with the others (all $P<0.05, \chi^{2}$-test; data not shown).

In addition, 78 paired tissue specimens from the first appearing local (skin; $n=26$ ) or regional (lymph nodes; $n=52$ ) metastatic tumour in this patient series were examined, selecting the largest tumour in case of multiple available lesions.

In 10 cases with discordant and wild-type first metastasis, two different levels from the same metastasis were examined: in five cases, two different formalin-fixed, paraffin-embedded (FFPE) blocks of tumour tissue from the same metastasis were examined, and in five cases, tumour tissue from two different levels of the same FFPE block was examined. In 4 of these 10 cases, subsequently appearing multiple metastases were examined $(n=6)$. These subsequent metastases were also loco-regional metastases.

Median age at diagnosis was 70 years and median thickness of the primary tumour was $3.6 \mathrm{~mm}$ (range $0.7-29.0 \mathrm{~mm}$ ). Complete information on patient survival, time and cause of death was available in all 255 cases. Last date of follow-up regarding survival was 31 December 2014 and median follow-up time for survivors was 115 months (range 72-203 months). During the follow-up

\begin{tabular}{|c|c|c|}
\hline & $\begin{array}{l}\text { Primary melanoma } \\
\qquad(n=194)\end{array}$ & $\begin{array}{c}\text { Metastatic melanoma } \\
\qquad(n=72)\end{array}$ \\
\hline \multicolumn{3}{|l|}{ TERT } \\
\hline Wild type (n) & $63(32 \%)$ & $26(36 \%)$ \\
\hline Mutation ( $n$ ) & 131 (68\%) & $46(64 \%)$ \\
\hline$-124 \mathrm{C}>\mathrm{T}(n)$ & $59(45 \%)$ & $18(39 \%)$ \\
\hline$-146 C>T(n)$ & $58(44 \%)$ & $25(54 \%)$ \\
\hline $\begin{array}{l}-138 /-139 \\
\text { CC > TT }(n)\end{array}$ & $12(9 \%)$ & $3(7 \%)$ \\
\hline $\begin{array}{l}-124 /-125 \\
\text { CC }>\text { TT }(n)\end{array}$ & $2(2 \%)$ & $0(0 \%)$ \\
\hline \multicolumn{3}{|c|}{ Abbreviation: TERT = telomerase reverse transcriptase. } \\
\hline
\end{tabular}

period, 88 patients (35\%) died of malignant melanoma and 76 (30\%) died of other causes. A summary of patient characteristics is given in Supplementary Table 1.

The Norwegian Data Inspectorate and the Regional Committee for Ethics in Research (Health Region III; 178.05) have approved this project. The study was performed in accordance with the Declaration of Helsinki Principles.

Clinico-pathologic variables. Clinical data and histologic variables were included: date of histologic diagnosis, sex, age at diagnosis, tumour anatomic site, tumour thickness according to Breslow (Breslow, 1970), level of invasion according to Clark (Clark et al, 1969), mitotic count, the mitotic marker $\mathrm{PHH} 3$ (Ladstein et al, 2012a), microscopic tumour ulceration (Ladstein et al, 2012a) and tumour necrosis (Ladstein et al, 2012b). In addition, previously recorded data on $B R A F$ mutation status was included (Hugdahl et al, 2016).

Tissue microarray. The tissue microarray (TMA) technique has been described and validated in several studies (Kononen et al, 1998; Nocito et al, 2001; Straume and Akslen, 2002). Three tissue cylinders (diameter $1.0 \mathrm{~mm}$ ) from representative tumour areas identified on H\&E-stained slides, such as the supra-basal area of the primary melanomas, were punched from archival blocks and mounted into a recipient paraffin block using a custom made precision instrument (Beecher Instruments, Silver Spring, MD, USA). Sections of the resulting TMA blocks $(5 \mu \mathrm{m})$ were made by standard technique.

Immunohistochemistry. Immunohistochemical staining was performed on $5 \mu \mathrm{m}$ TMA sections. Sufficient tumour tissue for immunohistochemistry was available in 248 of the 255 primary melanoma cases and 68 of the 78 paired loco-regional metastatic melanomas. For detection of TERT expression, the slides were dewaxed with xylene/ethanol before microwave antigen retrieval for $30 \mathrm{~min}$ in Target Retrieval Solution (DAKO 1699, Glostrup, Denmark) ( $\mathrm{pH}$ 6). Endogenous peroxidase activity was prevented by treating the slides with peroxidase block (DAKO S2001) for $8 \mathrm{~min}$. The slides were incubated with an anti-telomerase catalytic subunit (hTERT) polyclonal rabbit antibody (dilution 1:125) (catalogue number 600-401-252) (Rockland, Limerick, PA, USA) overnight at $4{ }^{\circ} \mathrm{C}$. The reliability of this antibody has been validated in the study by $\mathrm{Wu}$ et al (2006). The staining procedure was performed using the anti-rabbit EnVision labelled polymer method (DAKO K4011) with 3-amino-9-ethylcarbazole (DAKO K3469) as substrate chromogen. Brief counterstaining was performed with

\begin{tabular}{|c|c|c|c|c|}
\hline & \multicolumn{4}{|c|}{ Primary tumour } \\
\hline & $\begin{array}{c}\text { TERT - } \\
146 \mathrm{C}>\mathrm{T} \\
(n=19)\end{array}$ & $\begin{array}{c}\text { TERT - } \\
124 \mathrm{C}>\mathrm{T} \\
(n=17)\end{array}$ & $\begin{array}{c}\text { TERT }-138 /- \\
139 \text { CC }>\text { TT } \\
(n=5)\end{array}$ & $\begin{array}{c}\text { TERT wild } \\
\text { type } \\
(n=17)\end{array}$ \\
\hline \multicolumn{5}{|l|}{$\begin{array}{l}\text { Loco- } \\
\text { regional } \\
\text { metastasis }\end{array}$} \\
\hline $\begin{array}{l}\text { TERT }-146 \\
C>T(n=18)\end{array}$ & $13(224 \%)$ & $3(5.2 \%)$ & $0(0 \%)$ & $2(3.4 \%)$ \\
\hline $\begin{array}{l}\text { TERT }-124 \\
C>T(n=14)\end{array}$ & $2(3.4 \%)$ & $10(17.2 \%)$ & $0(0 \%)$ & $2(3.4 \%)$ \\
\hline $\begin{array}{l}\text { TERT }-138 /- \\
139 \mathrm{CC}>\mathrm{TT} \\
(n=3)\end{array}$ & $0(0 \%)$ & $0(0 \%)$ & $3(5.2 \%)$ & 0 (\%) \\
\hline $\begin{array}{l}\text { TERT wild } \\
\text { type }(n=23)\end{array}$ & $4(6.9 \%)$ & $4(6.9 \%)$ & $2(3.4 \%)$ & $\begin{array}{c}13 \\
(22.4 \%)\end{array}$ \\
\hline
\end{tabular}


Table 3. TERT mutation status in 10 discordant cases with wild type first metastasis and a mutation-positive primary tumour

\begin{tabular}{|c|c|c|c|c|c|c|c|c|c|}
\hline \multirow[t]{2}{*}{ Case } & \multicolumn{3}{|c|}{$\begin{array}{l}\text { First appearing metastasis (different } \\
\text { part of tumour) }\end{array}$} & \multicolumn{3}{|c|}{ Second appearing metastasis } & \multicolumn{3}{|c|}{ Third appearing metastasis } \\
\hline & TERT & Location & $\begin{array}{l}\text { Synchronous/ } \\
\text { metachronous }^{\text {a }}\end{array}$ & TERT & Location & $\begin{array}{l}\text { Synchronous/ } \\
\text { metachronous }^{\text {b }}\end{array}$ & TERT & Location & $\begin{array}{l}\text { Synchronous/ } \\
\text { metachronous }^{c}\end{array}$ \\
\hline $558^{d}$ & Mutated & $\begin{array}{l}\text { Lymph } \\
\text { node }\end{array}$ & Metachronous & Mutated & Skin & Synchronous & Mutated & Skin & Synchronous \\
\hline $567^{e}$ & $\begin{array}{l}\text { Wild } \\
\text { type }\end{array}$ & Skin & Metachronous & Mutated & Skin & Metachronous & & & \\
\hline $582^{e}$ & $\begin{array}{l}\text { Wild } \\
\text { type }\end{array}$ & $\begin{array}{l}\text { Lymph } \\
\text { Node }\end{array}$ & Synchronous & & & & & & \\
\hline $615^{d}$ & Mutated & Skin & Metachronous & & & & & & \\
\hline $641^{d}$ & $\begin{array}{l}\text { Wild } \\
\text { type }\end{array}$ & $\begin{array}{l}\text { Lymph } \\
\text { Node }\end{array}$ & Metachronous & & & & & & \\
\hline $699^{e}$ & $\begin{array}{l}\text { Wild } \\
\text { type }\end{array}$ & $\begin{array}{l}\text { Lymph } \\
\text { Node }\end{array}$ & Synchronous & Mutated & Skin & Metachronous & Mutated & Skin & Metachronous \\
\hline $729^{d}$ & Mutated & $\begin{array}{l}\text { Lymph } \\
\text { Node }\end{array}$ & Metachronous & & & & & & \\
\hline $\begin{array}{l}\text { Abbrevi } \\
\text { a Compa } \\
\text { b } \text { Comp } \\
{ }^{c} \text { Compa } \\
\text { d }_{\text {Tumou }} \\
\text { e }_{\text {Tumou }}\end{array}$ & $\begin{array}{l}\text { on: } F F P E=f \\
d \text { with prim } \\
d \text { with first } \\
d \text { with secor } \\
\text { tissue from a } \\
\text { tissue from a }\end{array}$ & $\begin{array}{l}\text { rmalin-fixed } p \\
y \text { tumour. } \\
\text { pearing meta } \\
\text { appearing } m \\
\text { other FFPE b } \\
\text { deeper level }\end{array}$ & $\begin{array}{l}\text { in-embedded. } \\
\text { s. } \\
\text { tasis. } \\
\text { of the tumour than origi } \\
\text { tumour in the same FF }\end{array}$ & ested. & y tested. & & & & \\
\hline
\end{tabular}

haematoxylin (DAKO S2020). Negative controls were obtained by omitting the primary antibody.

Evaluation of staining. Expression of hTERT was characterised by cytoplasmic staining of melanoma cells. The staining intensity was recorded as either negative, weak, moderate or strong (0-3) and proportion of tumour cells stained was recorded as $1(<10 \%)$, $2(10-50 \%)$ or $3(>50 \%)$. A staining index (SI) was calculated as the product of intensity and proportion scores (Straume and Akslen, 1997). A subset of cases $(n=69)$ was scored blindly by two observers (EH and RGL) showing good inter-observer agreement $(\kappa=0.77, P<0.01)$. Evaluation of the cases was done blinded for patient characteristics and outcome.

DNA extraction. In primary melanoma and metastases, the whole circumference of the tumour area was identified and marked by the pathologist (LAA) on H\&E-stained slides. Marked tumour tissue was manually dissected from five subsequent $10 \mu \mathrm{m}$ sections of FFPE tissue. DNA was extracted using the QIAmp DNA FFPE Tissue Kit (Qiagen 56404, Hilden, Germany) for the first 130 primary melanoma cases and the E.Z.N.A tissue DNA kit (Omega Biotek D3396, Norcross, GA, USA) for the remaining cases (with no significant difference in mutation frequency) and for the metastatic tumour cases. The DNA concentration was determined by the NanoDrop Spectrophotometer.

Sanger sequencing. PCR amplification was performed using the TaKaRa LATaq DNA polymerase (Takara Bio, Mountain View, CA, USA) or AmpliTaq Gold PCR Master Mix (Applied Biosystems, Foster City, CA, USA). PCR amplification of the TERT promoter region was performed using primers hTERT_short_F 5'-CAGCGCTGCCTGAAACTC-3' and hTERT_short_R $5^{\prime}$-GTCCTGCCCCTTCACCTT-3' (163 bp product) as described by Horn et al (2013). PCR products were enzymatically treated by Illustra ExoProStar 1-Step before sequenced in both directions using the BigDye Terminator Cycle Sequencing Kit version 1.1
(Applied Biosystems). The sequence reactions were analysed on the Applied Biosystems 3500xL Genetic Analyzer using Sequencing Analysis software, version 6 (Applied Biosystems) and the electropherograms were examined manually.

Statistics. Statistical analyses were performed using the IBM Statistical Package for the Social Sciences version 23 (IBM Corp., Armonk, NY, USA). Associations between categorical variables were assessed by the Pearson's $\chi^{2}$-test. Comparison of two or more continuous variables not following the normal distribution was performed using the Mann-Whitney's U-test or Kruskal-Wallis tests. $\kappa$ statistics was used in analyses of inter-observer agreement of categorical data.

Univariate analyses of time to death due to malignant melanoma were performed using the product-limit procedure (Kaplan-Meier method) with the log-rank test for differences, and with date of histological diagnosis as the starting point for analyses of primary melanomas and date of first metastasis as the starting point for analyses of metastatic melanomas. Patients who died of other causes were censored at the date of death. The influence of co-variates on patient survival was analysed by the proportional hazards method, and tested by the likelihood ratio (lratio) test. All results were considered significant if $P<0.05$.

\section{RESULTS}

Telomerase reverse transcriptase promoter mutation status. TERT promoter mutation status was assessed by Sanger sequencing in cases with sufficient tissue (primary melanomas; $n=194$, metastatic melanomas; $n=72)$. One hundred and thirty-one $(68 \%)$ of the primary melanomas were mutation positive; $45 \%$ had the $-124 \mathrm{C}>\mathrm{T}$ mutation and $44 \%$ showed $-146 \mathrm{C}>\mathrm{T}$; $11 \%$ had less frequent mutations $(-138 /-139 \mathrm{CC}>\mathrm{TT}$ and $-124 /-125$ CC $>$ TT). Forty-six (64\%) of the first appearing metastases were 
Table 4. TERT promoter mutation and associations with clinico-pathologic features and BRAF mutation in primary melanoma $(n=194)$

\begin{tabular}{|c|c|c|c|}
\hline & \multicolumn{3}{|c|}{ TERT promoter status } \\
\hline & WT & Mutated & $P$-value \\
\hline $\begin{array}{l}\text { Tumour thickness }(\mathrm{mm}) \\
\text { median }\end{array}$ & 3.7 & 4.7 & $0.10^{a}$ \\
\hline Ulceration $^{\mathbf{b}}$ & & & $\mathrm{NS}^{\mathrm{c}}$ \\
\hline Absent (n) & 30 (48\%) & 51 (39\%) & \\
\hline Present (n) & $32(52 \%)$ & $79(61 \%)$ & \\
\hline $\begin{array}{l}\text { Mitotic count }\left(\mathrm{no} / \mathrm{mm}^{2}\right) \\
\text { median }\end{array}$ & 4,7 & 6,6 & $0.18^{a}$ \\
\hline $\begin{array}{l}\mathrm{PHH} 3\left(\mathrm{no} / \mathrm{mm}^{2}\right) \\
\text { median }\end{array}$ & 33 & 44 & $0.08^{a}$ \\
\hline Tumour necrosis & & & $N S^{c}$ \\
\hline Absent (n) & $46(73 \%)$ & 92 (70\%) & \\
\hline Present $(n)$ & 17 (27\%) & 39 (30\%) & \\
\hline Age (years) median & 67 & 73 & $0.10^{a}$ \\
\hline Gender & & & $N S^{c}$ \\
\hline Female $(n)$ & $32(51 \%)$ & $53(40 \%)$ & \\
\hline Male $(n)$ & $31(49 \%)$ & $78(60 \%)$ & \\
\hline Anatomic location $^{d}$ & & & $\mathrm{NS}^{\mathrm{c}}$ \\
\hline Truncus (n) & 17 (27\%) & 39 (30\%) & \\
\hline Other sites $(n)$ & 45 (73\%) & $90(70 \%)$ & \\
\hline BRAF status ${ }^{\mathbf{e}}$ & & & $\mathrm{NS}^{\mathrm{c}}$ \\
\hline WT (n) & 32 (56\%) & $80(66 \%)$ & \\
\hline V600E $(n)$ & $25(44 \%)$ & $41(34 \%)$ & \\
\hline \multicolumn{4}{|c|}{$\begin{array}{l}\text { Abbreviations: } N S=\text { not significant; } W T=\text { wild type. } \\
a_{\text {Mann-Whitney } U \text {-test. }} \\
b_{\text {Two missing cases. }} \\
c_{\chi^{2} \text {-test. }} \\
d_{\text {Three missing cases. }} \\
e_{16 \text { Missing cases due to insufficient tissue. }}\end{array}$} \\
\hline
\end{tabular}

mutation positive; of these, $39 \%$ harboured the $-124 \mathrm{C}>\mathrm{T}, 54 \%$ showed $-146 \mathrm{C}>\mathrm{T}$ and $7 \%$ had $-138 /-139 \mathrm{CC}>\mathrm{TT}$ (Table 1 and Supplementary Figure S1).

There was sufficient tumour tissue in both the primary and matched metastatic lesions in 58 cases. Of these, TERT promoter mutation was present in $41(71 \%)$ of the primary tumours and in $35(60 \%)$ of the corresponding first appearing metastases. Regarding concordance, 10 cases $(17 \%)$ had a TERT promoter mutation in the primary tumour but not in the paired metastases, whereas 4 cases $(7 \%)$ had a TERT promoter mutation in the metastatic tumour, but not in the primary tumour. Altogether, 14 cases $(24 \%)$ had discordant status in terms of presence versus absence of TERT mutation, among which $71 \%$ did not show a mutation in the metastatic tumour (Table 2).

To investigate potential tumour heterogeneity, TERT mutation status was re-analysed in the 10 discordant cases with the absence of mutations in the first appearing metastases and a mutation-positive primary tumour, now including a different area of the metastatic lesion. In addition, among these 10 discordant cases, mutations were also analysed in subsequent metastases, which occurred in four cases. Altogether, in 6 of the 10 cases, TERT wild type was confirmed when re-analysing different regions of the same metastasis, whereas in four cases a TERT mutation was present. Among four of the 10 cases with subsequent metastases, 3 such cases were TERT mutation positive, whereas 1 case had a wild-type tumour. When looking at all metastatic lesions, including subsequent tumours, 6 out of 10 cases had a TERT mutation and 4 out of 10 cases were TERT wild type (Table 3).
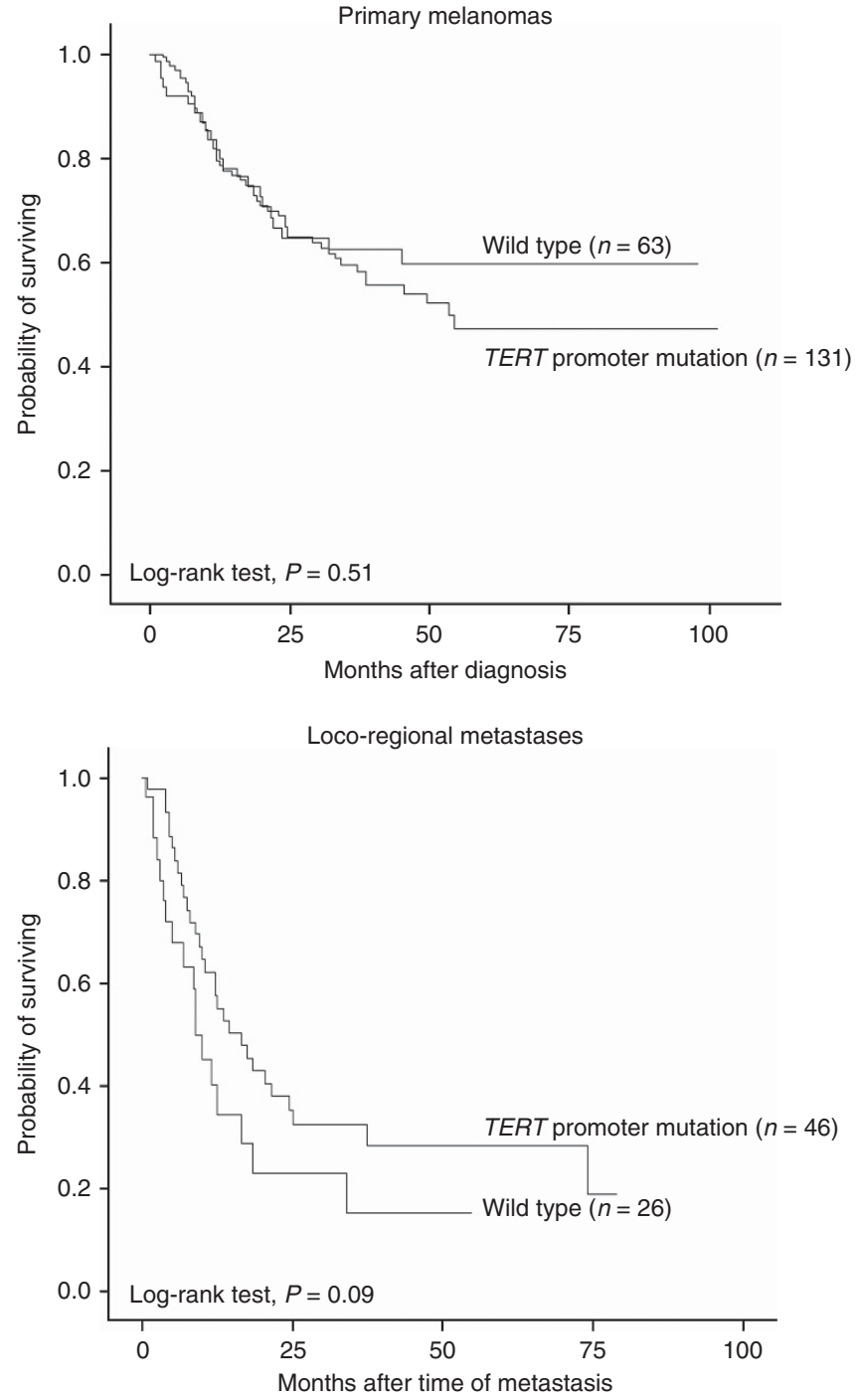

Figure 1. Survival curves by TERT promoter mutation status in primary melanoma $(n=194)$ and loco-regional metastases $(n=72)$ (KaplanMeier method, log-rank significance test).

Telomerase reverse transcriptase promoter mutation status and associations with clinico-pathologic features and BRAF mutations. Among TERT promoter-mutated primary melanomas, there were trends for increased tumour thickness $(P=0.10$, Mann-Whitney test), increased $\mathrm{PHH} 3$ count for proliferation $(P=0.08$, Mann-Whitney test $)$ and higher patient age $(P=0.098$, Mann-Whitney test) (Table 4), whereas there were no associations between mutation and level of invasion according to Clark, tumour ulceration, tumour necrosis or anatomic location.

TERT mutations tended to be more frequent in $B R A F$ wild type than BRAF-V600E-mutated melanomas, although not significant. TERT-mutated cases (66\%) were BRAF wild type, whereas coexistence of the two mutations was present in $23 \%$ of the primary melanomas (Table 4).

Survival analyses according to TERT promoter mutations. TERT mutation in the primary tumours $(n=194)$ was not associated with reduced recurrence-free survival, measured as time from diagnosis of the primary tumour to first metastasis or melanoma-specific survival (Figure 1). In addition, there was no difference in survival between the different TERT promoter mutations. When analysing the combined TERT/BRAF mutation status, there was a trend for reduced survival among cases with coexisting TERT and BRAF mutations compared with all others 

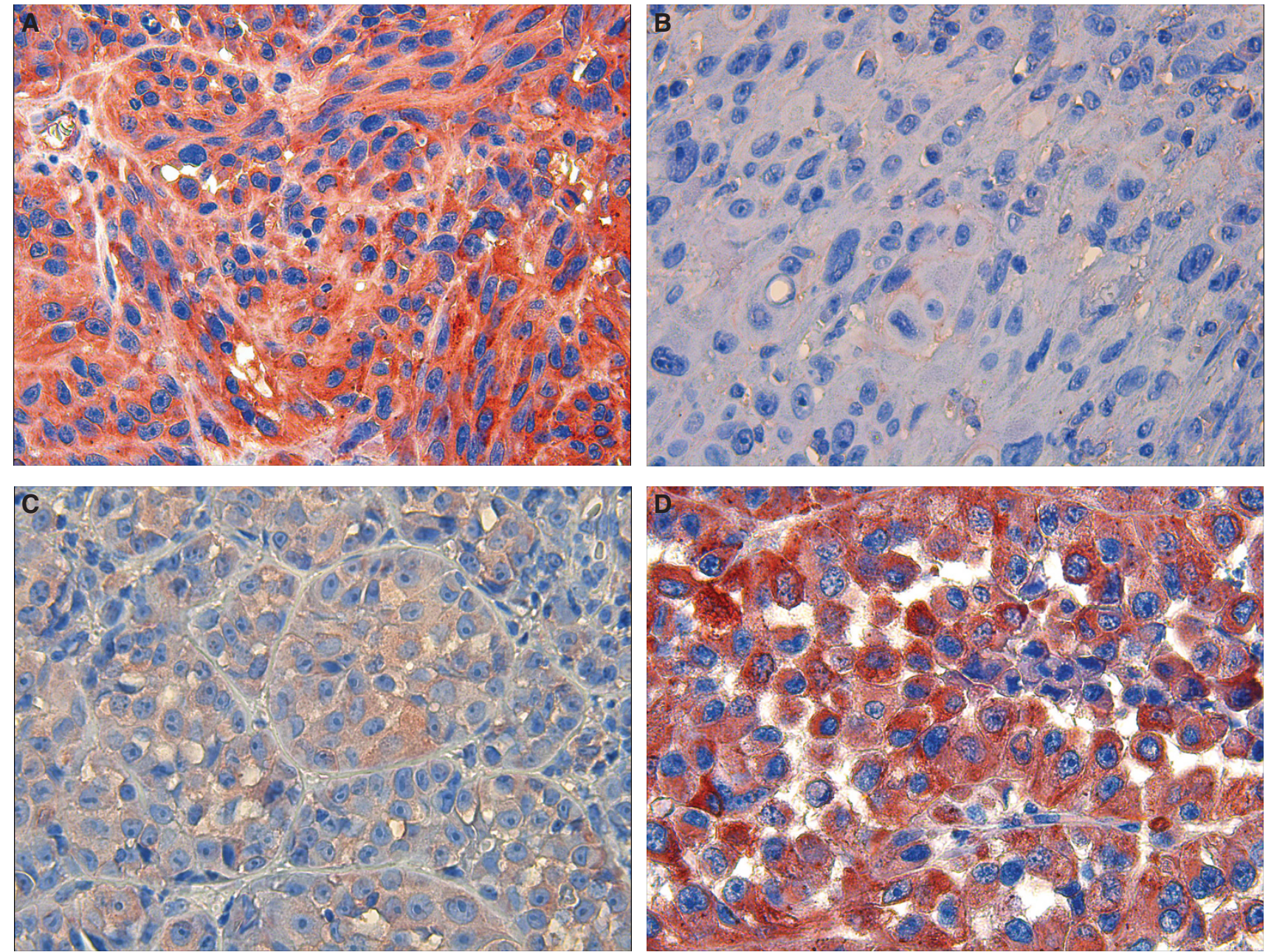

Figure 2. Immunohistochemical staining. Immunohistochemical staining showing two pairs (A-D) with discordant TERT expression: TERT-positive primary melanoma (A) with a TERT-negative metastasis (B), TERT-negative primary melanoma (C) with a TERT-positive metastasis (D).

$(P=0.098$, log-rank test) (Supplementary Figure S2). In the metastatic setting $(n=72)$, there was a trend for reduced melanoma-specific survival in TERT wild-type melanoma $(P=0.09$, log-rank test) (Figure 1$)$. Finally, combinations of TERT mutation status among paired primary and metastatic lesions $(n=58)$ showed no association with survival (Supplementary Figure S3).

Telomerase reverse transcriptase protein expression and association with TERT promoter mutation, clinico-pathologic features and survival. Immunohistochemical staining obtained with the TERT antibody was assessed in 248 primary melanomas and 68 paired loco-regional metastases. The staining was cytoplasmic and generally homogenous, and differences in staining intensity between tumour areas (heterogeneity) were rarely observed. Telomerase reverse transcriptase expression was categorised according to SI as either negative or positive with cut-off values based on the median (SI 4) in primary melanomas. Telomerase reverse transcriptase expression was positive in $44 \%$ of primary melanomas $(n=108)$ and $16 \%$ of loco-regional metastatic melanomas $(n=11)$ (Figure 2$)$.

Positive TERT expression in primary melanomas was associated with increased tumour thickness $(P=0.009$, Mann-Whitney's test), with a trend for presence of tumour necrosis $(P=0.056$, $\chi^{2}$-test) (Table 5). Further, positive TERT expression in primary melanoma was associated with reduced survival in univariate analysis $(P=0.048$, log-rank test) (Figure 3$)$, with borderline significance in multivariate analysis $(P=0.087)$ (Supplementary
Table 2). There was a trend for association of positive TERT expression with reduced survival in metastatic melanoma $(P=0.067$, log-rank test) (Figure 3$)$.

There was no significant correlation between TERT mutation status and TERT protein expression in primary $(P=0.31$, MannWhitney test) or metastatic tumours $(P=0.90$, Mann-Whitney test). Among primary tumours with positive TERT protein expression, $30 \%(n=27)$ did not have a TERT promoter mutation (Table 5).

There was sufficient tumour tissue in matched primary and metastatic lesions in 66 cases. Among these, TERT expression was positive in $36(55 \%)$ of the primary tumours, compared with 18 (27\%) of the metastatic tumours. Twenty-three cases (35\%) were TERT expression positive in the primary tumour but negative in the paired metastatic lesion; five cases $(8 \%)$ were TERT expression positive in the metastatic tumour, but not in the matched primary tumour. Altogether, TERT expression status was discordant in 28 cases (42\%) (Supplementary Table 3).

\section{DISCUSSION}

We here found that $68 \%$ of the primary melanoma and $64 \%$ of loco-regional metastases harbored TERT promoter mutations. This frequency in primary tumours is relatively high compared to previous studies (Griewank et al, 2014; Heidenreich et al, 2014; Populo et al, 2014; Nagore et al, 2016a,2016b). As a possible explanation, TERT mutations are reported to be more frequent in 
Table 5. TERT protein expression and associations with clinico-pathologic features and TERT promoter mutation in primary melanoma $(n=248)$

\begin{tabular}{|c|c|c|c|}
\hline & \multicolumn{3}{|c|}{ TERT protein expression ${ }^{a}$} \\
\hline & Negative & Positive & $P$-value \\
\hline $\begin{array}{l}\text { Tumour thickness (mm) } \\
\text { Median }\end{array}$ & 3,1 & 4,0 & $0.009^{b}$ \\
\hline $\begin{array}{l}\text { Ulceration }^{c} \\
\text { Absent (n) } \\
\text { Present (n) } \\
\end{array}$ & $\begin{array}{l}68 \text { (49\%) } \\
70(51 \%) \\
\end{array}$ & $\begin{array}{l}47(44 \%) \\
59(58 \%) \\
\end{array}$ & $N S^{d}$ \\
\hline $\begin{array}{l}\text { Mitotic count }\left(\mathrm{no} / \mathrm{mm}^{2}\right) \\
\text { median }\end{array}$ & 4,0 & 4,3 & $N S^{d}$ \\
\hline $\begin{array}{l}\text { Tumour necrosis } \\
\text { Absent (n) } \\
\text { Present }(n)\end{array}$ & $\begin{array}{l}112(80 \%) \\
28(20 \%)\end{array}$ & $\begin{array}{l}75(69 \%) \\
33(31 \%)\end{array}$ & $0.06^{d}$ \\
\hline Age (years) median & 70 & 71 & $N S^{b}$ \\
\hline $\begin{array}{l}\text { Gender } \\
\text { Female (n) } \\
\text { Male (n) }\end{array}$ & $\begin{array}{l}61(44 \%) \\
79(56 \%)\end{array}$ & $\begin{array}{l}51(47 \%) \\
57(53 \%)\end{array}$ & $N S^{d}$ \\
\hline $\begin{array}{l}\text { Anatomic location } \\
\text { Truncus (n) } \\
\text { Other sites (n) }\end{array}$ & $\begin{array}{l}41(29 \%) \\
99(71 \%)\end{array}$ & $\begin{array}{l}35(33 \%) \\
70(67 \%)\end{array}$ & $N S^{d}$ \\
\hline $\begin{array}{l}\text { TERT promoter status } \\
\text { WT (n) } \\
\text { Mutation (n) }\end{array}$ & $\begin{array}{l}36(35 \%) \\
67(65 \%) \\
\end{array}$ & $\begin{array}{l}27(30 \%) \\
63(70 \%) \\
\end{array}$ & $N S^{d}$ \\
\hline $\begin{array}{l}\text { Abbreviations: NS }=\text { not sig } \\
\text { scriptase; } W T=\text { wild type. } \\
\text { a Cut-off point SI median qu } \\
\text { b }_{\text {Mann-Whitney test. }} \\
c_{\text {Three missing cases. }} \\
d_{\chi^{2} \text {-test. }} \\
e_{55} \text { Missing cases. }\end{array}$ & $\mathrm{SI}=$ staining & TERT $=$ telom & e reverse tran \\
\hline
\end{tabular}

nodular melanomas compared with other subtypes (Heidenreich et al, 2014; Macerola et al, 2015; Nagore et al, 2016a). In addition, our series has a rather high median age, and TERT mutations have been associated with increased age at diagnosis (Heidenreich et al, 2014; Nagore et al, 2016a).

A possible explanation for the lack of prognostic impact in primary nodular and loco-regional metastatic melanomas might be that TERT mutations have lost their impact at these advanced stages of tumour progression, and that mutations in other genes are important for further progress, like CDKN2A, PTEN or TP53 (Hodis et al, 2012; Shain et al, 2015; Hayward et al, 2017). In support of this hypothesis, a relatively high TERT mutation discordance rate was found in paired primary and metastatic lesions, with $71 \%$ of discordant cases being TERT mutation negative in metastases. This might indicate that, in a subgroup of the tumours, TERT promoter mutation is not required for further progression at the stage of loco-regional metastasis.

To elucidate the possibility that the observed discordancy could be due to tumour heterogeneity, we re-analysed TERT mutation status in the ten discordant and wild-type metastases in other regions of the tumour and we also analysed TERT mutation status in subsequent metastases among these discordant cases. Thus, we found that six of the 10 first appearing metastases were TERT wildtype when re-tested in other intra-tumour regions, whereas 4 of 10 metastases were TERT mutated when re-analysed. Among four cases with subsequent metastases, three lesions were TERT mutated, whereas one case was wild type. This indicates that both intra- and inter-tumoural heterogeneity of TERT mutation status appear to be present in cutaneous melanoma.

Furthermore, we found no correlation between TERT mutations and increased TERT protein expression. Among primary melanomas with positive TERT protein expression, $30 \%$ did not have a
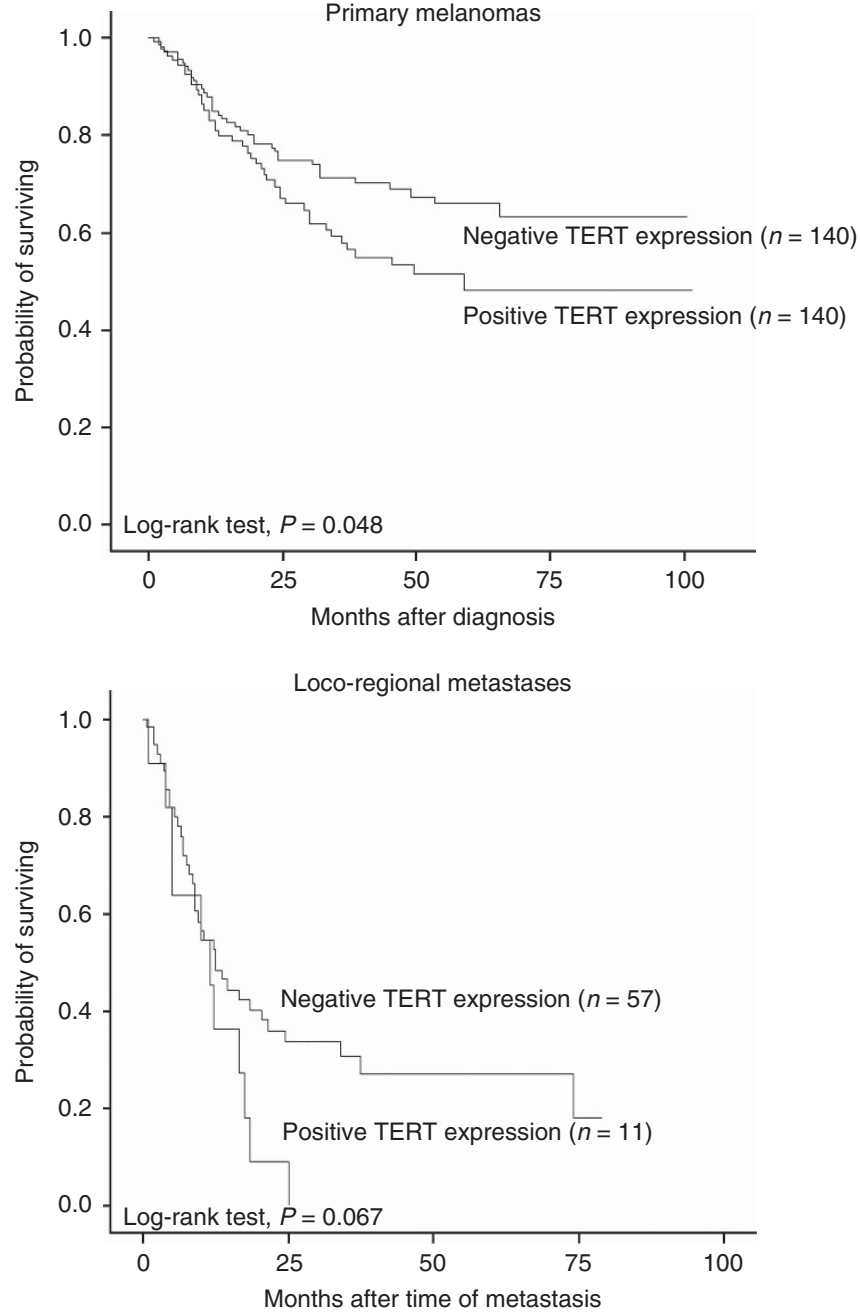

Figure 3. Survival curves by TERT protein expression in primary melanoma $(n=248)$ and loco-regional metastases $(n=68)$ (KaplanMeier method, log-rank significance test).

TERT promoter mutation. There are several proposed alternative mechanisms of telomerase activation, which could explain this observation, such as alternative splicing of TERT mRNA (Wong et al, 2014) and epigenetic alterations such as DNA methylation (Lai et al, 2005; Renaud et al, 2007). In a recent study of melanomas in adolesents and young adults, methylation of the TERT promoter, but not TERT promoter mutations, was associated with reduced recurrence-free survival (Seynnaeve et al, 2017).

We studied, for the first time using a melanoma cohort of sufficient size, TERT mutations and TERT protein expression status in paired primary and metastatic lesions, finding a high degree of discordancy for both. This supports the theory of melanoma being a complex and heterogenous disease, with tumours also evolving over time (Katona et al, 2007; Shain et al, 2015). A possible explanation is that both TERT promoter mutated and wildtype tumour cells are present in the primary melanoma, as indicated by our findings, both clones capable of giving rise to metastases. The frequency and significance of discordancy should be further studied.

In conclusion, we found that TERT promoter mutations are highly frequent in both primary and metastatic melanomas, which could be due to the nodular subtype and old patient age in our cohort. Importantly, we report that the mutation status changed in $24 \%$ of the cases during tumour progression. However we found no prognostic impact of TERT mutations. As a novel finding, TERT protein expression was significantly associated with increased 
tumour thickness and reduced patient survival, but was not related to TERT promoter mutation status.

\section{ACKNOWLEDGEMENTS}

We thank Gerd Lillian Hallseth, Bendik Nordanger and Randi Hope Lavik for excellent technical assistance. This work was partly supported by the Research Council of Norway through its Centres of Excellence funding scheme, project number 223250. Other funding sources were University of Bergen, Research Council of Norway (grant number 802630), Norwegian Cancer Society (grant number 803149) and Helse Vest Research Fund (grant number 911873).

\section{CONFLICT OF INTEREST}

The authors declare no conflict of interest.

\section{REFERENCES}

Akincilar SC, Khattar E, Boon PL, Unal B, Fullwood MJ, Tergaonkar V (2016) Long-range chromatin interactions drive mutant TERT promoter activation. Cancer Discov 6: 1276-1291.

Bell RJ, Rube HT, Kreig A, Mancini A, Fouse SD, Nagarajan RP, Choi S, Hong C, He D, Pekmezci M, Wiencke JK, Wrensch MR, Chang SM, Walsh KM, Myong S, Song JS, Costello JF (2015) Cancer. The transcription factor GABP selectively binds and activates the mutant TERT promoter in cancer. Science 348: 1036-1039.

Breslow A (1970) Thickness, cross-sectional areas and depth of invasion in the prognosis of cutaneous melanoma. Ann Surg 172: 902-908.

Clark Jr. WH, From L, Bernardino EA, Mihm MC (1969) The histogenesis and biologic behavior of primary human malignant melanomas of the skin. Cancer Res 29: 705-727.

Ekedahl H, Lauss M, Olsson H, Griewank KG, Schadendorf D, Ingvar C, Jonsson G (2016) High TERT promoter mutation frequency in non-acral cutaneous metastatic melanoma. Pigment Cell Melanoma Res 29: 598-600.

Griewank KG, Murali R, Puig-Butille JA, Schilling B, Livingstone E, Potrony M, Carrera C, Schimming T, Moller I, Schwamborn M, Sucker A, Hillen U, Badenas C, Malvehy J, Zimmer L, Scherag A, Puig S, Schadendorf D (2014) TERT promoter mutation status as an independent prognostic factor in cutaneous melanoma. J Natl Cancer Inst 106.

Hanahan D, Weinberg RA (2011) Hallmarks of cancer: the next generation. Cell 144: 646-674.

Hayward NK, Wilmott JS, Waddell N, Johansson PA, Field MA, Nones K, Patch AM, Kakavand H, Alexandrov LB, Burke H, Jakrot V, Kazakoff S, Holmes O, Leonard C, Sabarinathan R, Mularoni L, Wood S, Xu Q, Waddell N, Tembe V, Pupo GM, De Paoli-Iseppi R, Vilain RE, Shang P, Lau LMS, Dagg RA, Schramm SJ, Pritchard A, Dutton-Regester K, Newell F, Fitzgerald A, Shang CA, Grimmond SM, Pickett HA, Yang JY, Stretch JR, Behren A, Kefford RF, Hersey P, Long GV, Cebon J, Shackleton M, Spillane AJ, Saw RPM, Lopez-Bigas N, Pearson JV, Thompson JF, Scolyer RA, Mann GJ (2017) Whole-genome landscapes of major melanoma subtypes. Nature 545: 175-180.

Heidenreich B, Nagore E, Rachakonda PS, Garcia-Casado Z, Requena C, Traves V, Becker J, Soufir N, Hemminki K, Kumar R (2014) Telomerase reverse transcriptase promoter mutations in primary cutaneous melanoma. Nat Commun 5: 3401.

Hodis E, Watson IR, Kryukov GV, Arold ST, Imielinski M, Theurillat JP, Nickerson E, Auclair D, Li L, Place C, Dicara D, Ramos AH, Lawrence MS, Cibulskis K, Sivachenko A, Voet D, Saksena G, Stransky N, Onofrio RC, Winckler W, Ardlie K, Wagle N, Wargo J, Chong K, Morton DL, Stemke-Hale K, Chen G, Noble M, Meyerson M, Ladbury JE, Davies MA, Gershenwald JE, Wagner SN, Hoon DS, Schadendorf D, Lander ES, Gabriel SB, Getz G, Garraway LA, Chin L (2012) A landscape of driver mutations in melanoma. Cell 150: 251-263.

Horn S, Figl A, Rachakonda PS, Fischer C, Sucker A, Gast A, Kadel S, Moll I, Nagore E, Hemminki K, Schadendorf D, Kumar R (2013) TERT promoter mutations in familial and sporadic melanoma. Science 339: 959-961.
Huang FW, Hodis E, Xu MJ, Kryukov GV, Chin L, Garraway LA (2013) Highly recurrent TERT promoter mutations in human melanoma. Science 339: 957-959.

Hugdahl E, Kalvenes MB, Puntervoll HE, Ladstein RG, Akslen LA (2016) BRAF-V600E expression in primary nodular melanoma is associated with aggressive tumour features and reduced survival. $\mathrm{Br} J$ Cancer 114: 801-808.

Katona TM, Jones TD, Wang M, Eble JN, Billings SD, Cheng L (2007) Genetically heterogeneous and clonally unrelated metastases may arise in patients with cutaneous melanoma. Am J Surg Pathol 31: 1029-1037.

Killela PJ, Reitman ZJ, Jiao Y, Bettegowda C, Agrawal N, Diaz Jr. LA, Friedman AH, Friedman H, Gallia GL, Giovanella BC, Grollman AP, He TC, He Y, Hruban RH, Jallo GI, Mandahl N, Meeker AK, Mertens F, Netto GJ, Rasheed BA, Riggins GJ, Rosenquist TA, Schiffman M, Shih IeM, Theodorescu D, Torbenson MS, Velculescu VE, Wang TL, Wentzensen N, Wood LD, Zhang M, Mclendon RE, Bigner DD, Kinzler KW, Vogelstein B, Papadopoulos N, Yan H (2013) TERT promoter mutations occur frequently in gliomas and a subset of tumors derived from cells with low rates of self-renewal. Proc Natl Acad Sci USA 110: 6021-6026.

Kononen J, Bubendorf L, Kallioniemi A, Barlund M, Schraml P, Leighton S, Torhorst J, Mihatsch MJ, Sauter G, Kallioniemi OP (1998) Tissue microarrays for high-throughput molecular profiling of tumor specimens. Nat Med 4: 844-847.

Ladstein RG, Bachmann IM, Straume O, Akslen LA (2012a) Prognostic importance of the mitotic marker phosphohistone $\mathrm{H} 3$ in cutaneous nodular melanoma. J Invest Dermatol 132: 1247-1252.

Ladstein RG, Bachmann IM, Straume O, Akslen LA (2012b) Tumor necrosis is a prognostic factor in thick cutaneous melanoma. Am J Surg Pathol 36: $1477-1482$.

Lai SR, Phipps SM, Liu L, Andrews LG, Tollefsbol TO (2005) Epigenetic control of telomerase and modes of telomere maintenance in aging and abnormal systems. Front Biosci 10: 1779-1796.

Li Y, Zhou QL, Sun W, Chandrasekharan P, Cheng HS, Ying Z, Lakshmanan M, Raju A, Tenen DG, Cheng SY, Chuang KH, Li J, Prabhakar S, Li M, Tergaonkar V (2015) Non-canonical NF-kappaB signalling and ETS1/2 cooperatively drive C250T mutant TERT promoter activation. Nat Cell Biol 17: 1327-1338.

Macerola E, Loggini B, Giannini R, Garavello G, Giordano M, Proietti A, Niccoli C, Basolo F, Fontanini G (2015) Coexistence of TERT promoter and BRAF mutations in cutaneous melanoma is associated with more clinicopathological features of aggressiveness. Virchows Arch 467: $177-184$.

Nagore E, Heidenreich B, Rachakonda S, Garcia-Casado Z, Requena C, Soriano V, Frank C, Traves V, Quecedo E, Sanjuan-Gimenez J, Hemminki K, Teresa Landi M, Kumar R (2016a) TERT promoter mutations in melanoma survival. Int J Cancer. 139(1): 75-84.

Nagore E, Heidenreich B, Requena C, Garcia-Casado Z, MartorellCalatayud A, Pont-Sanjuan V, Jimenez-Sanchez AI, Kumar R (2016b) TERT promoter mutations associate with fast-growing melanoma. Pigment Cell Melanoma Res 29: 236-238.

Nocito A, Bubendorf L, Tinner EM, Suess K, Wagner U, Forster T, Kononen J, Fijan A, Bruderer J, Schmid U, Ackermann D, Maurer R, Alund G, Knonagel H, Rist M, Anabitarte M, Hering F, Hardmeier T, Schoenenberger AJ, Flury R, Jager P, Fehr JL, Schraml P, Moch H, Mihatsch MJ, Gasser T, Sauter G (2001) Microarrays of bladder cancer tissue are highly representative of proliferation index and histological grade. J Pathol 194: 349-357.

Ofner R, Ritter C, Heidenreich B, Kumar R, Ugurel S, Schrama D, Becker JC (2016) Distribution of TERT promoter mutations in primary and metastatic melanomas in Austrian patients. J Cancer Res Clin Oncol 143(4): 613-617.

Populo H, Boaventura P, Vinagre J, Batista R, Mendes A, Caldas R, Pardal J, Azevedo F, Honavar M, Guimaraes I, Manuel Lopes J,

Sobrinho-Simoes M, Soares P (2014) TERT promoter mutations in skin cancer: the effects of sun exposure and X-irradiation. J Invest Dermatol 134: 2251-2257.

Renaud S, Loukinov D, Abdullaev Z, Guilleret I, Bosman FT, Lobanenkov V, Benhattar J (2007) Dual role of DNA methylation inside and outside of CTCF-binding regions in the transcriptional regulation of the telomerase hTERT gene. Nucleic Acids Res 35: 1245-1256. 
Seynnaeve B, Lee S, Borah S, Park Y, Pappo A, Kirkwood JM, Bahrami A (2017) Genetic and epigenetic alterations of TERT are associated with inferior outcome in adolescent and young adult patients with melanoma. Sci Rep 7: 45704.

Shain AH, Yeh I, Kovalyshyn I, Sriharan A, Talevich E, Gagnon A, Dummer R, North J, Pincus L, Ruben B, Rickaby W, D'arrigo C, Robson A, Bastian BC (2015) The genetic evolution of melanoma from precursor lesions. N Engl J Med 373: 1926-1936.

Stern JL, Theodorescu D, Vogelstein B, Papadopoulos N, Cech TR (2015) Mutation of the TERT promoter, switch to active chromatin, and monoallelic TERT expression in multiple cancers. Genes Dev 29: 2219-2224.

Straume O, Akslen LA (1997) Alterations and prognostic significance of p16 and 553 protein expression in subgroups of cutaneous melanoma. Int $J$ Cancer 74: 535-539.

Straume O, Akslen LA (2002) Importance of vascular phenotype by basic fibroblast growth factor, and influence of the angiogenic factors basic fibroblast growth factor/fibroblast growth factor receptor-1 and ephrinA1/EphA2 on melanoma progression. Am J Pathol 160: 1009-1019.

Vinagre J, Almeida A, Populo H, Batista R, Lyra J, Pinto V, Coelho R, Celestino R, Prazeres H, Lima L, Melo M, Da Rocha AG, Preto A, Castro P, Castro L, Pardal F, Lopes JM, Santos LL, Reis RM, Cameselle-Teijeiro J,
Sobrinho-Simoes M, Lima J, Maximo V, Soares P (2013) Frequency of TERT promoter mutations in human cancers. Nat Commun 4: 2185.

Wong MS, Wright WE, Shay JW (2014) Alternative splicing regulation of telomerase: a new paradigm? Trends Genet 30: 430-438.

Wu YL, Dudognon C, Nguyen E, Hillion J, Pendino F, Tarkanyi I, Aradi J, Lanotte M, Tong JH, Chen GQ, Segal-Bendirdjian E (2006)

Immunodetection of human telomerase reverse-transcriptase (hTERT) re-appraised: nucleolin and telomerase cross paths. J Cell Sci 119: 2797-2806.

Zygouris P, Tsiambas E, Tiniakos D, Karameris A, Athanassiou AE, Kittas C, Kyroudi A (2007) Evaluation of combined h-TERT, bcl-2, and caspases 3 and 8 expression in cutaneous malignant melanoma based on tissue microarrays and computerized image analysis. J BUON 12: 513-519.

This work is published under the standard license to publish agreement. After 12 months the work will become freely available and the license terms will switch to a Creative Commons AttributionNonCommercial-Share Alike 4.0 Unported License.

Supplementary Information accompanies this paper on British Journal of Cancer website (http://www.nature.com/bjc) 